JSAP: Journal Syariah and Accounting Public

ISSN: 2622-3538

Available Online at https://journal.umgo.ac.id/index.php/JSAP/index

Vol. 4, No. 2 Desember 2021

DOI: $10.31314 /$ jsap.4.2.47-56.2021

\title{
ANALISIS PENGARUH FLYPAPER EFFECT TERHADAP EFISIENSI BELANJA DAERAH DI PROVINSI GORONTALO
}

\section{Lukfiah Irwan Radjak ${ }^{1,}$ Syarif K. Latarang ${ }^{2}$}

1. 2., Program Studi Akuntansi, Universitas Muhammadiyah Gorontalo, Indonesia

Email; lukfiahradjak@umgo.ac.id, Syarifklatarang@gmail.com

Info Artikel: Diterima: 22 November 2021, Disetujui: 24 Sesembar 2021, Publish 24 Desember 2021

\begin{abstract}
:
The research was conducted in Gorontalo Provincial government. The purpose of this research was to find out how the Flypaper Effect affects the efficiency of regional spending in Gorontalo Province. This study uses the Multiple Regression Method where the dependent variable is Regional Expenditure and the independent variable is the General Allocation Fund and Regional Original Income. From the results of research conducted partially the General Allocation Fund has a positive effect on regional spending and Regional Original Income does not have a positive effect on Regional Expenditures. Meanwhile, the General Allocation Fund and Regional Original Revenue have a positive effect on regional expenditures simultaneously. And during the 2016-2020 research period, the Flypaper Effect phenomenon occurred in Gorontalo Province. Meanwhile, the efficiency ratio of Regional Expenditures to Regional Income from 2016-2020 shows inefficient results.
\end{abstract}

Keywords: Flypaper Effect , Regional Expenditure

\begin{abstract}
Abstrak:
Penelitian dilakukan di pemerintah Provinsi Gorontalo.adapun tujuan dari penelitian ini untuk mengetahui bagaimana Pengaruh Flypaper Effect Terhadap Efisiensi Belanja Daerah di Provinsi Gorontalo. Penelitian ini Mengunakan Metode Regresi Berganda dimana variabel terikat adalah Belanja Daerah dan variabel bebas adalah Dana Alokasi Umum dan Pendapatan Asli Daerah. Dari hasil penelitian yang dilakukan secara parsial Dana Alokasi Umum berpengaruh positif terhadap belanja daerah dan Pendapatan Asli Daerah tidak berpengaruh Positif terhadap Belanja Daerah. Sedangkan secara simultan Dana Alokasi Umum dan Pendapatan Asli daerah berpengaruh Positif terhadap Belanja daerah. Serta selama periode penelitian tahun 2016-2020 terjadi fenomena Flypaper Effect pada Provinsi Gorontalo Sedangkan Rasio efisiensi Belanja Daerah terhadap pendapatan daerah dari tahun 2016-2020 menujukan hasil yang kurang efisien.
\end{abstract}

Kata kunci : Flypaper Effect, Belanja Daerah

\begin{aligned} & \hline \hline PENDAHULUAN untuk mendukung pendanaan atau \\ & Pembentukan Undang-undang tentang penyerahan urusan kepada pemerintah \\ & perimbangan keuangan antara pemerintah daerah yang diatur dalam Undang-undang \\ & pusat dan pemerintah daerah dimaksud Nomor 23 tahun 2014 tentang pemerintah \\ & \hline\end{aligned}


daerah. Pendanaan tersebut menganut prinsip money follows function yang mengandung makna bahwa pendanaan mengikuti fungsi pemerintah yang menjadi kewajiban dan tanggung jawab masing-masing tingkat pemerintah.

Perimbangan keuangan antara pemerintah dan pemerintah daerah mencangkup pembagian keuangan antara pemerintah daerah secara proporsional, demokratis, adil dan transparan dengan memperhatikan potensi, kondisi dan kebutuhan daerah.

Dalam rangka penyelenggaraan otonomi daerah, penyerahan, pelim-pahan dan penugasan urusan pem-erintah pusat kepada pemerintah daerah secara nyata dan bertanggung jawab harus diikuti dengan pengaturan, pembagian dan pemanfaatan sumber daya secara adil, termasuk perimbangan keuangan antara pemerintah pusat dan pemerintah daerah. Sebagai daerah otonom, penyelenggaraan pem-erintahan dan pelayanan dilakukan berdasarkan prinsip-prinsip transpa-ransi, partisipasi dan akuntabilitas. (Darise,2009)

Undang-undang Nomor 23 Tahun 2014 menjelaskan bahwa dalam pelaksanaan kewenangan pemerintah daerah, pemerintah pusat akan mentransfer dana perimbangan yang terdiri Dana Alokasi Umum (DAU), Dana Alokasi Khusus (DAK), dan Dana Bagi hasil (DBH) yang terdiri dari pajak dan sumber daya alam lainnya. Selain dari dana perimbangan tersebut, pemerintah daerah mempunyai sumber pendanaan sendiri yang berasal dari Pendapatan Asli Daerah (PAD) dan pendapatan lain-lain yang sah. Kebijakan penggunaan semua dana tersebut diserahkan kepada pemerintah daerah.

Daerah yang kemampuan fiskal rendah akan mendapatkan DAU dalam jumlah yang relatif besar, sebaliknya daerah yang mempunyai kemampuan fiskal tinggi akan mendapatkan DAU dalam jumlah yang relatif kecil. Hal ini diharapkan agar kemandirian daerah menjadi semakin tinggi seiring dengan meningkatkan kapasitas fiskal daerah, yang menyebabkan tanggung jawab pemerintah untuk memberikan DAU bisa lebih dikurangi agar tidak terjadi permasalahan di suatu pemerintah (Halim, dalam Susansi dan Indriani, 2017)

Dana transfer dari pemerintah pusat diharapkan secara efektif dan efisien digunakan oleh pemerintah daerah untuk meningkatkan pelayanan kepada masyarakat. Kebijakan pengg-unaan dana tersebut sudah seharusnya pula secara transparan dan akuntabel. Berdasarkan desentralisasi maka pem-erintah daerah diharapkan lebih mampu menggali sumbersumber keuangan. Khususnya untuk memenuhi kebutuhan pembiayaan pemerintah dan pemba-ngunan di daerah tersebut melalui PAD.

Di temukan fenomena flypaper effect mengidentifikasi bahwa pem-erintah daerah dalam memenuhi kebutuhan publik 
senantiasa cenderung lebih merespon atas pengeluaran belanja daerah dari transfer "berhemat" dalam optimalisasi pengeluaran yang berasal dari PAD. Flypaper effect juga bisa mempengaruhi kecenderungan belanja pemda pada periode selan-jutnya, sehingga efek tersebut akan berdampak jangka panjang. (Iman Santoso dalam Transana dan Racmaeny,2017).

Flypaper effect merupakan suatu fenomena yang merujuk kepada pengaruh dari transfer dana dan pendapatan daerah terhadap kebijakan belanja daerah. Ketika penerimaan berasal dari transfer, maka stimulasi belanja yang ditimbulkan akan berbeda dengan stimulasi yang timbul dari pendapatan daerah, terutama pajak daerah. Ketika respon belanja daerah lebih besar terhadap transfer diban-dingkan dengan respon belanja daerah terhadap pendapatan daerah. Fenom-ena flypaper effect membawa implikasi lebih luas bahwa transfer akan menin-gkatkan belanja daerah yang lebih besar dibandingkan penerimaan tran-sfer tersebut. (Kuncoro dalam Eni, 2016).

Selain Flypaper Belanja daerah juga mencerminkan kebijakan pem-erintah daerah dan arah kebijakan pembangunan daerah (Mahmudi dalam Fathiyah, 2012) Belanja daerah sangat rentan akan terjadinya inefisiensi dan kebocoran, maka perencanaan peng-endalian dan pengawasan terhadap belanja sangat penting untuk dilakukan. Belanja daerah setelah dibelanjakan dan dilaporkan dalam Laporan Reali-sasi Anggaran biasanya dianalisis untuk dijadikan dasar evaluasi, koreksi dan perbaikan ke depan.

Halim dalam Susanti dan Indrian, (2017), mengatakan permasalahan ya-ng dihadapi daerah pada umumnya berkaitan dengan penggalian sumber-sumber pajak dan retribusi daerah yang merupakan salah satu komponen dari PAD masih belum memberikan kontribusi signifikan terhadap pene-rimaan daerah secara keseluruhan serta kemampuan perencanaan dan pengawasan keuangan lemah. Peran PAD dalam membiayai kebutuhan pengeluaran daerah sangat kecil dan bervariasi antara daerah, yaitu kurang dari $10 \%$ hingga $50 \%$.

Pada saat ini Rata-rata PAD setiap provinsi masih belum mampu membiayai kebutuhan daerah dan sering menggunakan dan transfer untuk belanja daerah sehingga terjadinya defisit anggaran. Menurut Direktorat Jenderal Perimbangan Keuangan, defisit APBD merupakan selisih kurang antara pendapatan daerah dan belanja daerah pada tahun anggaran yang sama. Defisit terjadi bila jumlah pendapatan lebih kecil daripada jumlah belanja. Berdasarkan sumber data yang didapat dari DJPK Kemenkeu Laporan Realisasi APBD Provinsi Gorontalo tahun 2020, Pendapatan Rp. 8.478.681.556.712 dan Belanja Rp. 8.639.641.847.333 selisihnya men-galami sebesar (Rp.160.960.290.621), Hal ini menandakan bahwa penda-patan dari 
Provinsi Gorontalo masih sangat kurang dibanding dengan belanja daerah yang cenderung sangat besar dan pemerintah belum mengo-ptimalkan PAD sebagai penyokong belanja pemerintah, Defisit anggaran yang terjadi karena tidak efisiensinya belanja daerah di Provinsi Gorontalo.

Tabel 1. Persentase Keuangan Provinsi Gorontalo Tahun 2018-2020

\begin{tabular}{cc}
\hline Uraian & $\begin{array}{c}\text { Persentase } \\
\text { Rata-Rata }\end{array}$ \\
\hline PAD & $0,642 \%$ \\
DAU & $1,028 \%$ \\
BD & $53,924 \%$ \\
\hline
\end{tabular}

Sumber: DJPK Kemenkeu. 2021

Dari tabel di atas dapat dilihat bahwa rata-rata persentase kenaikan DAU lebih besar daripada persentase kenaikan PAD, dalam hal ini dari besarnya nilai transfer dari pada nilai PAD menggambarkan kecenderungan menggunakan dana transfer untuk belanja daerah. Secara keseluruhan perkembangan keuangan daerah menunjukan hubungan yang tidak simetris, dimana perubahan partum-buhan DAU dengan belanja Daerah. Hal ini terlihat indikasi kuat perilaku belanja daerah sangat dipengaruhi sumber penerimaan berupa dana transfer yaitu DAU sehingga akan melemahkan kemampuan daerah dalam membiayai kebutuhan sendiri. Bisa dikatakan bahwa di Provinsi Gorontalo kurang mengoptimalkan sumber potensipotensi yang baru atau yang sudah ada dalam daerah guna untuk meningkatkan PAD.

Berdasarkan permasalahan di-atas bahwa kemandirian daerah meru-pakan suatu tuntutan wajib mengingat dalam era globalisasi, setiap daerah harus mampu dan bisa bersaing dengan daerah lainnya, terutama dalam hal menggali sumbersumber potensi yang baru atau pun yang sudah ada di daerah guna untuk meningkatkan PAD yang nantinya bisa digunakan untuk membiayai pembangunan daerah. Mengetahui bahwasannya kriteria yang digunakan untuk tingkat kemampuan daerah dalam mengelola rumah tangga sendiri dalam meningkatkan PAD berupa pajak dan retribusi daerah yang diharapkan menjadi salah satu sumber pembiayaan penyelenggaraan peme-rintah dan pembangunan daerah, untuk pemerataan pembangunan, meningkatkan dan memeratakan kesejahteraan masyarakat. (Kusumah dalam Muhammad, 2015)

Tujuan Penelitian ini adalah untuk mengetahui pengaruh secara simultan DAU dan PAD terhadap belanja di Provinsi Gorontalo Tahun 2016-2020 Daerah, Untuk mengetahui secara Parsial Penagruh DAU terhadap Belanja Daerah di Provinsi Gorontalo Tahun 2016-2020 dan Pengaruh PAD terhadap Belanja Daerah di Provinsi Gorontalo Tahun 2016-2020, Untuk mengetahui analisis rasio efisiensi di Provinsi Gorontalo tahun 2016-2020. 


\section{METODE PENELITIAN}

Jenis Penelitian ini merupakan penelitian kuantitatif deskriptif yang melakukan perhitungan-perhitungan terhadap data keuangan yang diperoleh untuk memecahkan masalah yang ada sesuai dengan tujuan penelitian. Penelitian ini dimaksud untuk meng-etahui Analisis pengaruh flypaper effect terhadap efisiensi belanja Daerah di provinsi gorontalo.

Dalam penelitian ini mengg-unakan analisis regresi berganda adalah analisis untuk mengetahui pen-garuh atau hubungan secara linear antara dua atau lebih variabel inde-penden terhadap varaibel dependen, dan untuk memprediksi atau mera-malkan suatu nilai variabel dependen berdasarkan variabel indenpenden (Priyatno, 2014). Dalam penelitian ini, persamaan regresi linier yang digunakan adalah sebagai berikut

$$
\begin{aligned}
& Y=a+\beta_{1} X_{1}+\beta_{2} X_{2} \\
& \text { Keterangan : } \\
& \mathrm{Y}=\text { Belanja Daerah } \\
& \text { a }=\text { Konstanta Regresi } \\
& \beta_{1}, \beta_{2}=\text { Koefisien Regresi } \\
& \mathrm{X}_{1}=\text { Dana Alokasi Umum } \\
& \text { X2 = Pendapatan Asli Daerah }
\end{aligned}
$$

\section{HASIL DAN PEMBAHASAN}

Data yang digunakan dalam penelitian ini adalah Laporan Realisasi Anggaran Pendapatan dan Belanja Daerah Provinsi Gorontalo yaitu pada tahun 2016-2020. Adapun variabel dalam penelitian ini adalah variabel bebas (X1) Dana Alokasi Umum, (X2) Pendapatan Asli Daerah, dan variabel terikat (Y) Belanja Daerah.

\section{Pengaruh Dana Alokasi Umum terhadap Belanja Daerah di Provinsi Gorontalo tahun 2016-2020}

Indikasi kuat perilaku belanja daerah sangat dipengaruhi oleh sumber penerimaan berupa dana transfer yaitu DAU sehingga akan melemahkan kemampuan daerah dalam membiayai kebutuhan sendiri. Jika DAU men-dominasi aspek pemasukan daerah sendiri hal ini menunjukan bahwa tingkat ketergantungan pemerintah daerah terhadap dana perimbangan masih tinggi untuk membiayai belanja daerah. peneliti menguji pengaruh jumlah DAU terhadap BD dengan mengunakan Uji T untuk mengukur tingkat signifikansi, maka perlu membandingkan antara $T_{\text {hitung }}$ dengan $T_{\text {tabel. }}$ Degree of Freedom (Df) dapat ditemukan dengan menggunakan rum-us $\mathrm{N}-\mathrm{K}-1, \mathrm{~N}$ dalam penelitian ini adalah jumlah sampel penelitian, $\mathrm{K}$ merupakan jumlah variabel bebas jika disubsitusikan maka akan menjadi 20-2-1 = 17 Df atau sebesar 1,739 sedangkan $T_{\text {hitung }}$ bernilai 29,494 yang dapat disimpulkan bahwa jumlah $\mathrm{T}_{\text {hitung }}$ lebih besar dari $\mathrm{T}_{\text {tabel }}$ artinya DAU berpengaruh positif dan signifikan terhadap belanja daerah. ini sejalan dengan analisi regresi liner berganda bahwa peningkatan DAU sebanyak $1 \%$, akan mempengaruhi kenaikan pem-biyaan belanja daerah meng-gunakan DAU sebanyak $2.612 \%$. Hasil penelitian ini sesuai 
dengan penelitian yang dilakukan oleh sarita (2019) yang meyatakan DAU memiliki pengaruh signifikan dan positif terhadap belanja daerah yang artinya Semakin besar DAU yang diterima menunjukan bahwa ketergantungan penggunaan dana transfer untuk membiayai belanja daerah. Ini berarti bahwa pemerintah provinsi Gorontalo belum mandiri dalam memenuhi kebutuhan financial dalam menjalankan roda pemerintahan yang mengakibatkan tujuan dari desen-tralisasi fiskal untuk menciptakan pemerintahan dalam aspek belanja daerah belum bisa tercapai.

\section{Pengaruh Pendapatan Asli Daerah Terhadap Belanja Daerah di Provinsi Gorontalo tahun 2016-2020.}

PAD merupakan sumber pend-apatan daerah yang dapat dijadikan sebagai tolak ukur bagi kinerja perekonomian suatu daerah. Setiap daerah harus mampu dan bisa bersaing dengan daerah lainnya, terutama dalam hal menggali sumbersumber potensi yang baru atau pun yang sudah ada di daerah guna untuk meningkatkan PAD yang na-ntinya bisa digunakan untuk membiayai pembangunan daerah tanpa ber-gantung pada pendapatan dana transfer, Mengetahui bahwasannya kriteria yang digunakan untuk tingkat kemampuan daerah dalam mengelola rumah tangga sendiri untuk men-ingkatkan PAD berupa pajak dan retribusi daerah yang diharapkan menjadi salah satu sumber pembiayaan penyelenggaraan pemerintah dan pembangunan daerah, untuk pemerataan pembangunan, meningkatkan dan memeratakan kesejahteraan mas-yarakat. (Kusumah dalam Muhammad, 2015). Pada penelitian yang dilakukan oleh peneliti mengenai pengaruh PAD yang berpengaruh terhadap belanja daerah dengan menguji secara parsial menunjukan bahwa PAD berpengaruh negatif dan signifikan terhadap belanja daerah. Degree of Freedom (DF) dihitung menggunakan rumus $\mathrm{N}-\mathrm{K}-1, \mathrm{~N}$ dalam penelitian ini adalah jumlah sampel data, $\mathrm{K}$ merupakan Variabel Bebas jika disubtitusikan maka akan menjadi 20-2-1 = 17 df sebesar 1,739 sedangkan $T_{\text {hitung }}$ 21,339. Ini berarti $T_{\text {hitung }}$ lebih kecil dari $T_{\text {tabel }}$ atau PAD berpengaruh negatif dan siqnifikan terhadap belanja daerah. Ini sejalan dengan hasil analisis melalui regresi linier berganda yang diiterpretasikan sebagai koefisien regresi setiap peningkatan $P A D$ sebanyak $1 \%$ akan mempengaruhi turunya belanja daerah yang menggunakan dana transfer sebanyak $-2.890 \%$. jika PAD menigkat maka akan mengurangi jumlah dana transfer untuk membiayai daerah dan terhindar dari fenomena flypapper effect. Hasil penelitian ini sesuai dengan penelitian yang dilakukan oleh Aisyah dkk (2016) bahwa berpengaruh signifikan dan negatif terhadap belanja daerah. Tentunya dengan mengha-silkan PAD yang tinggi daerah dapat lebih memaksimalkan lagi untuk meni-ngkatkan sumber-sumber keuangan daerahnya untuk digali lagi dan tidak ketergantungan terhadap 
dana per-imbangan untuk membiayai daerah.

\section{Pengaruh Dana Alokasi Umum dan Pendapatan Asli Daerah Terhadap Belanja Daerah di Provinsi Gorontalo tahun 2016-2020.}

Daerah diharapkan mampu mengalokasikan sumber dana ini pada sektor-sektor produktif sehingga dapat mendorong peningkatan investasi di daerah yang kemudian berdampak terhadap meningkatnya sumber penerimaan PAD. PAD yang seha-rusnya menjadi ciri dari kemandirian daerah, namun banyak daerah yang masih memiliki ketergantungan yang besar pada dana transfer. Proporsi DAU terhadap penerimaan daerah masih yang relatif tinggi dibandingkan dengan penerimaan PAD. Pada penelitian yang telah dilalkukan oleh peneliti mengenai pengaruh DAU, PAD terhadap Belanja Daerah yang diuji secara simultan, Pengujian secara simultan dilakukan untuk mengetahui ada tidaknya pengaruh bersama variabel bebas terhadap variabel terikat dan hasil menunjukan bahwa DAU dan PAD secara bersama-sama berp-engaruh siqnifikan terhadap Belanja Daerah, Hasil ini ditunjukan oleh nilai $F_{\text {hitung }}$ yakni 472,471 mempunyai nilai lebih besar dari nilai $F_{\text {tabel }}$ yakni 3.74 , artinya Variabel tersebut memiliki peran yang cukup andil dalam belanja daerah dilhat dari hasil regresi koefisien yang signifikan terhadap belanja daerah. Hasil ini sejalan dengan penelitian yang dilakukan oleh Wiwin dkk (2016) Hasil uji hipotesis variable DAU dan PAD Hasil regresi diperoleh nilai $F_{\text {hitung sebesar }}$ 165,7230 lebih besar dari nilai $F_{\text {tabel }}$ pada $\alpha=$ 1\% sebesar 99,50 artinya bahwa, secara bersama-sama variabel $D A U$ dan PAD memiliki pengaruh terhadap belanja daerah.

\section{Penentuan Flypaper Effect}

Untuk menentukan terjadi atau tidaknya flypaper effect maka peneliti menggunakan pendekatan flypaper effect yakni menurut Tresch (2002) untuk melihat apakah terjadi flypaper effect, dapat dilihat dari perbandingan antara koefisien DAU dan koefisien PAD, Jika koefisien DAU > Koefisien PAD maka terjadi flypaper effect. Pada penelitian yang dilakukan oleh peneliti koefisien DAU sebesar 2.612 dan Koefisein PAD -2.890 artinya koefisien DAU lebih besar dibanding dengan PAD, maka peneliti menyimpulkan bahwa telah terjadi fenomena flypapper effect pada pemerintah Provinsi Gorontalo tahun 2016-2020. Hal ini juga sejalan dengan penelitian terdahulu yang telah dilakukan oleh Haris dan Nayang (2020) dengan hasil pada tahun 2018 Provinsi Gorontalo merupakan salah satu Provinsi yang mengalami terjadinya fenomena fly-paper effect yang bersumber dari besar jumlah DAU yang diterima oleh pemerintah Provinsi Gorontalo untuk membiayai daerah dibanding dengan pendapatan daerah. 


\section{Efisiensi Belanja Daerah}

Belanja daerah dipergunakan dal-am rangka mendanai pelaksanaan urusan pemerintahan yang menjadi wewenang provinsi atau kabupa-ten/kota yang terdiri dari urusan wajib, urusan pilihan dan urusan yang penangannya dalam bagian atau bidang tertentu yang dapat dilaks-anakan bersama antara pemerintah dan pemerintah daerah yang ditetapkan dengan ketentuan perundang-und-angan. Belanja penyelenggaraan uru-san wajib diprioritaskan untuk me-lindungi dan meningkatkan kualitas kehidupan masyarakat dalam upaya memenuhi kewajiban daerah. Jika pemerintah membiayai semua itu menggunakan penadapatan asli daerah maka akan efisien bagi kemandirian pemerintah karena tidak bergantung pada pendapatan dana transfer yang diberikan pemerintah pusat, untuk mengukur efisiensi belanja daerah maka menggunakan rasio efisiensi.

Rasio efisiensi menggambarkan perbandingan antara besarnya biaya yang dikeluarkan untuk memperoleh pendapatan dengan realisasi pen-dapatan yang diterima. Rasio efisiensi menggambarkan tingkat kemampuan pemerintah dalam mengefisiensikan biaya yang dikeluarkan oleh pem-erintahpenilaian efisiensi dikatakan sangat efisien apabila hasil perhitungan dibawah $60 \%$. Semakin kecil rasio ini, maka semakin efisien, begitu pula sebaliknya, (Mardiasmo dalam Vera dkk, 2014)
Rasio Efisiensi $=\frac{\text { Realisasi Belanja Daerah }}{\text { Realisasi Pendapatan Daerah }} \mathrm{X} 100 \%$

Tabel. 2 Rasio Efisiensi Belanja Daerah Provinsi Gorontalo

\begin{tabular}{cc}
\hline Tahun & Rasio Efisiensi \\
\hline $\mathbf{2 0 1 6}$ & $100,73 \%$ \\
$\mathbf{2 0 1 7}$ & $98,03 \%$ \\
$\mathbf{2 0 1 8}$ & $101,55 \%$ \\
$\mathbf{2 0 1 9}$ & $99,92 \%$ \\
$\mathbf{2 0 2 0}$ & $96,88 \%$ \\
\hline
\end{tabular}

Sumber : Hasil Olah Data, 2021

Dari tabel diatas dapat dilihat Berdasarkan analisis tingkat rasio efisiensi belanja daerah terhadap pendapatan daerah ditahun 2016-2020, pengelolaan keuangan daerah Provinsi Gorontalo dapat dikategorikan kurang efisien pada tahun 2016 rasio efisien 100,76\% dengan kriteria kurang efisien dan pada tahun 2017 menurun menjadi $98,03 \%$ dengan kriteria kurang efisien dan pada tahun 2018 dengan rasio efisien $101,55 \%$ meningkat $1 \%$ dari tahun 2016 dan meningkat $3 \%$ dari tahun 2017 dengan kriteria kurang efisien dan pada tahun 2019 menurun 2\% dari tahun 2018 dengan rasio efisien 99,92\% dan pada tahun 2020 mengalami penurunan 3\% dari tahun 2019 dengan rasio efisien 96,88\%. Kemudian pada tahun 2016 dan 2018 terjadi defisit anggaran yaitu selisih kurang antara pendapatan daerah dan belanja daerah pada tahun anggaran yang sama, defisit tersebut dapat mempengaruhi Laporan perubahan saldo anggaran lebih (LP-SAL). 


\section{KESIMPULAN}

1. Hasil penelitian dengan men-ggunakan aplikasi SPSS melalui uji koefisien regresi linier ber-ganda menunjukan bahwa setiap peningkatan Dana Alokasi Umum sebanyak 1\%, akan mempengaruhi kenaikan pembiayaan belanja daerah menggunakan DAU sebanyak $2.612 \%$. Dari uji secara parsial menunujukan bahwa DAU berpengaruh sign-ifikan dan positif terhadap belanja daerah.

2. Hasil penelitian dengan men-ggunakan aplikasi SPSS melalui uji koefisien regresi linier ber-ganda menunjukan bahwa setiap peningkatan PAD sebanyak $1 \%$ akan mem-pengaruhi turunya belanja daerah yang menggunakan dana transfer sebanyak $2,890 \%$. Dari uji secara parsial menunujukan bahwa PAD berpe-ngaruh signifikan dan negatif terhadap belanja daerah.

3. Hasil olah data menggunakan SPSS melalui uji simultan menu-njukan bahwa DAU dan PAD sama-sama berpengaruh terha-dap belanja daerah.

\section{Saran}

Berdasarkan hasil penelitian dan kesimpulan yang telah diuraikan di atas, maka saran penelitian ini sebagai berikut :

1. Pemerintah provinsi perlu mengoptimalkan sumber-sumber PAD untuk meningkatkan pendapatan daerah sendiri, serta dapat mene-kan besarnya dana transfer untuk membiayai daerahyang diberikan oleh pemerintah pusat kepada pemerintah provinsi Gorontalo agar terhindar dari fenomena flypaper effect

2. Pemerintah Provinsi Gorontalo juga dapat menggali potensi-potensi daerah yang dimiliki sehingga dapat meningkatkan pendapatan asli daerah, untuk dapat menciptkan keuangan daerah yang mandiri sesuai dengan tujuan otonomi daerah.

3. Dengan adanya perhitungan analisis Rasio efisien pendapatan dan belanja daearah yang telah dianalisis oleh peneliti, dihara-pkan pemerintah daerah Provinsi Gorontalo dapat lebih melaksanakan anggaran secara efisien serta mengurangi ketergantungan terhadap pemerintah pusat deng-an cara memaksimalkan PAD.

4. Kepada peneliti selanjutnya agar bisa menambahkan variabel beb-as lainya seperti Dana Alokasi Khusus, Dana Bagi Hasil yang secara teori dapat mempengaruhi belanja daerah yang dapat meni-mbulkan fenomena Flypaper ef-fect.

\section{Referensi}

Darise, (2009). Pengelolaan Keuangan Daerah. Edisi 2, Jakarta Barat: PT. Indeks Permata Putri Median

Eni, (2016). Analisis Flypaper Effect Pada Belanja Daerah Kab-upaten/Kota Di Provinsi D.I Yogyakarta Tahun 20082014. Skripsi. Fakultas Ekonomi Universitas Sanata Dharma. (https://respository.usd.ac.id) diakses pada 10 maret 2021

Haris, Nayang. (2020). Analisis flypaper effect pada DAU, dana alokasi khusus, dana bagi hasil, dan pendapatan asli 
daerah terhadap belanja daerah Provinsi di Indonesia. JEA: Jurnal Eksplorasi Akuntansi . Vol. 2 No 3, Seri c 3144-3159

Nabilah, A. N., Soelistyo, A., \& Kusuma, H. (2016). Analisis Flypaper Effect PAD dan DAU Terhadap Belanja Daerah di Provinsi Kalimantan Timur Tahun 2010-2014. Jurnal Ekonomi Pembangunan, 14(2), 190-203.

Mohammad, (2015). Analisis Kemam-puan Keuangan Daerah Dan Flypaper Effect Dalam Pelak-sanaan Otonomi Daerah (Studi Kasus Kabupaten jepara Tahun 2001-2013). Skripsi. Fakultas Ekonomi Dan Bisnis Universitas Diponegoro.(https://eprints.undip.ac.id) diakses pada tanggal 5 maret 2021

Susanti dan Indriani, (2017). Flypaper Effect Pada Pendapatan Asli Daerah (PAD) dan DAU (DAU) Terhadap Belanja Pemerintah Daerah Kabupaten Nganjuk Periode 2012-2016: Jurnal Akuntansi Dewantara

Sarita, (2019). Flypaper Effect Pada DAU, Dana Alokasi Khusus Dan Pendapatan Asli Daerah Terhadap Belanja Daerah Pada Pemerintah Kabupaten/Kota Di Provinsi Sumatera Utara. Skripsi. Fakultas Ekonomi Dan Bisnis. Universitas Sumatera Utara.

Transna, rachmaeny, (2017). Analisis Flypaper Effect Pengelolaan Keuangan Daerah di kota Jayapura.JMB: Jurnal manaje-men \& bisnis . pp 9-21

Vera dkk, (2014). Analisis efisiensi dan efektivitas serta kemandirian pengelolaan keuangan daerah di kabupaten minahasa utara. Jurnal mahasiswa Unsrat

Wiwin, Paulus. (2016). Flypaper Effect pada DAU (DAU) dan Pendapatan asli daerah (PAD) serta pengaruhnya terhadap belanja daerah kabupaten/kota di Sulawesi tengah.
Jurnal Pembangunan Ekonomi dan Keuangan Daerah.

Undang-Undang No. 23 Tahun 2014 tentang kewenangan pemerintah daerah 